Research article

\title{
p53 protein accumulation predicts resistance to endocrine therapy and decreased post-relapse survival in metastatic breast cancer
}

\author{
Hiroko Yamashita ${ }^{1}$, Tatsuya Toyama ${ }^{1}$, Mariko Nishio', Yoshiaki Ando ${ }^{1}$, Maho Hamaguchi ${ }^{1}$, \\ Zhenhuan Zhang ${ }^{1}$, Shunzo Kobayashi' ${ }^{1}$, Yoshitaka Fujiii and Hirotaka Iwase ${ }^{2}$
}

\author{
1Oncology and Immunology, Nagoya City University Graduate School of Medical Sciences, Kawasumi 1, Mizuho-ku, Nagoya 467-8601, Japan \\ ${ }^{2}$ Breast and Endocrine Surgery, Kumamoto University, 1-1-1 Honjo, Kumamoto 860-8556, Japan \\ Corresponding author: Hiroko Yamashita, hirokoy@med.nagoya-cu.ac.jp \\ Received: 5 Feb 2006 Revisions requested: 11 Apr 2006 Revisions received: 16 Jun 2006 Accepted: 25 Jul 2006 Published: 25 Jul 2006 \\ Breast Cancer Research 2006, 8:R48 (doi:10.1186/bcr1536) \\ This article is online at: http://breast-cancer-research.com/content/8/4/R48 \\ (c) 2006 Yamashita et al.; licensee BioMed Central Ltd. \\ This is an open access article distributed under the terms of the Creative Commons Attribution License (http://creativecommons.org/licenses/by/2.0), \\ which permits unrestricted use, distribution, and reproduction in any medium, provided the original work is properly cited.
}

\begin{abstract}
Introduction Endocrine therapy is the most important treatment option for women with hormone receptor-positive breast cancer. The potential mechanisms for endocrine resistance involve estrogen receptor (ER)-coregulatory proteins and cross-talk between ER and other growth factor-signaling networks. However, the factors and pathways responsible for endocrine resistance are still poorly identified.

Materials and methods The expression of HER2, p53, and Ki67 was examined by immunohistochemistry in primary breast tumour specimens from 73 metastatic breast cancer patients who received first-line treatment with endocrine therapy on relapse, and analysed to determine whether expression of these molecular markers affected the response to endocrine therapy.

Results Of the 73 invasive ductal carcinomas, $12.3 \%, 21.9 \%$, and $35.6 \%$ were positive for HER2 overexpression, p53 protein

accumulation, and Ki67 expression, respectively. All patients received endocrine therapy as first-line treatment for metastatic breast cancer; 34 patients $(46.6 \%)$ responded. Patients with primary breast tumours that had $\mathrm{p} 53$ protein accumulation and Ki67 expression showed significantly more resistance to endocrine therapy $(P=0.0049$ and $P=0.024$, respectively). There were also tendencies for HER2 overexpression to correlate with resistance to endocrine therapy, but this did not reach significance. p53 protein accumulation and HER2 overexpression significantly reduced post-relapse survival $(P<$ 0.0001 and $P=0.001$, respectively), and these factors were also statistically significant in a multivariate analysis.

Conclusion These data suggest that p53 protein accumulation is helpful in selecting patients who may benefit from endocrine therapy and is a prognostic marker in hormone receptor-positive metastatic breast cancer.
\end{abstract}

\section{Introduction}

Endocrine therapy has become the most important treatment option for women with estrogen receptor (ER)-positive breast cancer. Nevertheless, many breast cancer patients with tumours expressing high levels of ER are unresponsive to endocrine therapy, and all patients with advanced disease eventually develop resistance to the therapy. The potential mechanisms behind either intrinsic or acquired endocrine resistance involve ER-coregulatory proteins and cross-talk between the ER pathway and other growth factor-signaling networks $[1,2]$. An understanding of the molecular mechanisms that modulate the activity of the estrogen-signaling network has enabled new ways of overcoming endocrine resistance to be developed.
Several specific proteins have been suggested to contribute to endocrine therapy resistance. HER2 overexpression might be associated with reduced efficacy of adjuvant endocrine therapy with tamoxifen [3-5]. De Laurentiis and colleagues recently conducted a meta-analysis and found that HER2-positive metastatic breast cancer was less responsive to any type of endocrine therapy [6].

Nearly one third of breast tumours have mutations in the $p 53$ gene, which are associated with high histological grade and rapid progression [7]. Immunohistochemical assays generally detect nuclear accumulation of the protein, which is often related to conformational alterations and a prolonged half-life of the encoded protein $[8,9]$. Mutation of the $p 53$ gene or over- 
Table 1

Clinicopathological characteristics of patients, primary breast tumours, and treatment

\begin{tabular}{|c|c|c|}
\hline & & Number of patients (percentage) \\
\hline Total number of patients & & 73 \\
\hline \multirow[t]{2}{*}{ Age at diagnosis (years) } & $\begin{array}{l}\leq 50 \\
>50\end{array}$ & $\begin{array}{l}34(46.6) \\
39(53.4)\end{array}$ \\
\hline & Range & 29 to 77 \\
\hline Tumour size $(\mathrm{cm})$ & $\begin{array}{l}<2.0 \\
\geq 2.0\end{array}$ & $\begin{array}{l}20(27.4) \\
53(72.6)\end{array}$ \\
\hline Number of positive lymph nodes & $\begin{array}{l}0 \\
1-3 \\
>3\end{array}$ & $\begin{array}{l}21(28.8) \\
20(27.4) \\
32(43.8)\end{array}$ \\
\hline Histological grade & $\begin{array}{l}1 \\
2 \\
3\end{array}$ & $\begin{array}{l}12(16.4) \\
42(57.5) \\
19(26.1)\end{array}$ \\
\hline Adjuvant therapy & $\begin{array}{l}\text { None } \\
\text { Endocrine therapy } \\
\text { Chemotherapy } \\
\text { Combined }\end{array}$ & $\begin{aligned} 5 & (6.9) \\
32 & (43.8) \\
2 & (2.7) \\
34 & (46.6)\end{aligned}$ \\
\hline \multirow[t]{2}{*}{ Disease-free interval (months) } & $\begin{array}{l}\text { Mean } \pm \text { SD } \\
\text { Median }\end{array}$ & $39.8 \pm 25.7$ \\
\hline & Range & 2 to 123 \\
\hline $\begin{array}{l}\text { First-line endocrine therapy for metastatic } \\
\text { breast cancer }\end{array}$ & $\begin{array}{l}\text { Tamoxifen } \\
\text { Aromatase inhibitors } \\
\text { LHRH agonist } \\
\text { LHRH agonist }+ \text { tamoxifen } \\
\text { Fulvestrant }\end{array}$ & $\begin{array}{l}56(76.7) \\
9(12.3) \\
3(4.1) \\
4(5.5) \\
1(1.4)\end{array}$ \\
\hline
\end{tabular}

$\mathrm{LHRH}$, luteinising hormone-releasing hormone; SD, standard deviation.

expression of its protein product has been identified in $14 \%$ to $52 \%$ of primary breast tumour specimens, and these alterations were found to be associated with poor prognosis in an analysis of more than 3,000 patients with primary breast cancer [10]. We recently analysed the expression of HER2, p53, and Ki67 in 506 invasive ductal carcinoma tissues and showed that the coexistence of HER2 overexpression and p53 protein accumulation was a strong prognostic molecular marker in breast cancer [11].

Apoptosis may represent a common mechanism whereby a variety of antitumour treatments results in cell death. Cells with loss of p53 gene function may be unable to undergo apoptosis and thus be resistant to these forms of therapy [12]. Because mutated protein might accumulate in cells, immunohistochemical staining has been a popular surrogate marker for p53 mutational status. Studies have been published that examined the predictive value of $p 53$ alterations at the gene level, or p53 expression status by immunohistochemistry (IHC), for response to chemotherapy. Many of these studies reported that p53 alterations predict resistance to anthracyclins [1319]; cyclophosphamide, methotrexate, and fluorouracil (CMF); or other agents [20-22]. However, of the few studies that have examined the association between p53 status and response to endocrine therapy [23-27], one study [27] reported a value for p53 in predicting endocrine resistance.
We previously described that expression of ER- $\alpha$ and progesterone receptor (PR) by $\mathrm{IHC}$ in primary breast tumours is predictive of response to endocrine therapy in patients with metastatic breast cancer who received endocrine therapy on relapse [28]. In this study, we examined the expression of HER2, p53, and Ki67 by IHC in primary breast tumour specimens from 73 patients with metastatic breast cancer who received first-line treatment with endocrine therapy on relapse, and analysed whether expression of these molecular markers affected the response to endocrine therapy.

\section{Materials and methods Patients and breast cancer tissues}

Breast tumour specimens from 73 female patients with metastatic breast cancer, who were treated at Nagoya City University Hospital (Nagoya, Japan) between 1982 and 2002, were included in this study (Table 1). The study protocol was approved by the institutional review board and conformed with the guidelines of the 1975 Declaration of Helsinki. All patients had undergone surgical treatment for primary breast cancer (either mastectomy or lumpectomy), and all primary tumours were ER- or PR-positive. After surgery, five patients (6.9\%) received no additional therapy. Of the remaining 68 patients, $32(43.8 \%)$ received systemic adjuvant therapy consisting of endocrine therapy (tamoxifen) alone, two (2.7\%) received chemotherapy alone, and $34(46.6 \%)$ received combined 


\begin{tabular}{|c|c|c|c|c|c|c|}
\hline & \multicolumn{2}{|c|}{ HER2 } & \multicolumn{2}{|c|}{ P53 } & \multicolumn{2}{|c|}{ Ki67 } \\
\hline & $\begin{array}{l}\text { Positive/total } \\
\text { (percentage) }\end{array}$ & $P$ & $\begin{array}{l}\text { Positive/total } \\
\text { (percentage) }\end{array}$ & $P$ & $\begin{array}{l}\text { Positive/total } \\
\text { (percentage) }\end{array}$ & $P$ \\
\hline Total & 9/73 (12.3) & & $16 / 73(21.9)$ & & $26 / 73(35.6)$ & \\
\hline \multicolumn{7}{|c|}{ Tumour size $(\mathrm{cm})$} \\
\hline$<2.0$ & $4 / 20(20.0)$ & 0.41 & $5 / 20(25.0)$ & 0.94 & $7 / 20(35.0)$ & $>0.99$ \\
\hline$\geq 2.0$ & $5 / 53(9.4)$ & & $11 / 53(20.8)$ & & 19/53 (35.8) & \\
\hline \multicolumn{7}{|c|}{ Number of positive lymph nodes } \\
\hline 0 & $1 / 22(4.5)$ & 0.34 & $3 / 22(12.6)$ & 0.41 & $6 / 22(27.2)$ & 0.47 \\
\hline$\geq 1$ & $8 / 51(15.7)$ & & $13 / 51(25.5)$ & & 20/51 (39.2) & \\
\hline \multicolumn{7}{|c|}{ Histological grade } \\
\hline 1 & $0 / 12(0)$ & 0.36 & $0 / 12(0)$ & 0.05 & $3 / 12(25.0)$ & 0.18 \\
\hline 2 & 6/42 (14.3) & & 9/42 (21.4) & & $13 / 42(31.0)$ & \\
\hline 3 & $3 / 19(15.8)$ & & 7/19 (36.8) & & $10 / 19(52.6)$ & \\
\hline \multicolumn{7}{|c|}{ Estrogen receptor- $\alpha$} \\
\hline Negative & $4 / 17(23.5)$ & 0.23 & $5 / 17(29.4)$ & 0.60 & $8 / 17(47.1)$ & 0.40 \\
\hline Positive & $5 / 56(8.9)$ & & $11 / 56(19.6)$ & & $18 / 56(32.1)$ & \\
\hline \multicolumn{7}{|c|}{ Progesterone receptor } \\
\hline Negative & $3 / 18(16.7)$ & 0.81 & $5 / 18(27.8)$ & 0.71 & $9 / 18(50.0)$ & 0.23 \\
\hline Positive & 6/55 (10.9) & & $11 / 55(20.0)$ & & $17 / 55(30.9)$ & \\
\hline
\end{tabular}

endocrine therapy and chemotherapy. Patients who were positive for axillary lymph node metastases received either oral administration of 5-fluorouracil derivatives for 2 years or a combination of cyclophosphamide, methotrexate, and fluorouracil (CMF). Patients were observed for disease recurrence at least once every 6 months for the first 5 years after the surgery and thereafter once every year.

\section{First-line endocrine therapy for metastatic breast cancer and response criteria}

When the patients relapsed and were diagnosed with metastatic breast cancer, they started endocrine therapy (Table 1). Patients were assessed monthly for clinical response, which was defined according to World Health Organization criteria as complete response, partial response, no change, and progressive disease. The presence of progressive disease indicated treatment failure; all other clinical responses were considered to show efficacy of treatment. Stable disease was included as a response to treatment because patients with stable disease clearly benefited clinically in metastatic breast cancer.

\section{Immunohistochemical analysis for ER- $\alpha$, PR, HER2, p53, and Ki67}

One 4- $\mu \mathrm{m}$ section of each submitted paraffin block was first stained with hematoxylin and eosin to verify that an adequate number of invasive ductal carcinoma cells were present, and the fixation quality was sufficient for immunohistochemical analysis as described previously $[11,28]$. Serial sections (4$\mu \mathrm{m})$ were prepared from selected blocks and float-mounted on adhesive-coated glass slides for ER- $\alpha$, PR, HER2, p53, or Ki67 staining. Primary antibodies included monoclonal mouse anti-human ER antibody (1D5; Dako Denmark A/S, Glostrup, Denmark) at 1:100 dilution for ER- $\alpha$, monoclonal mouse anti- 
Figure 1

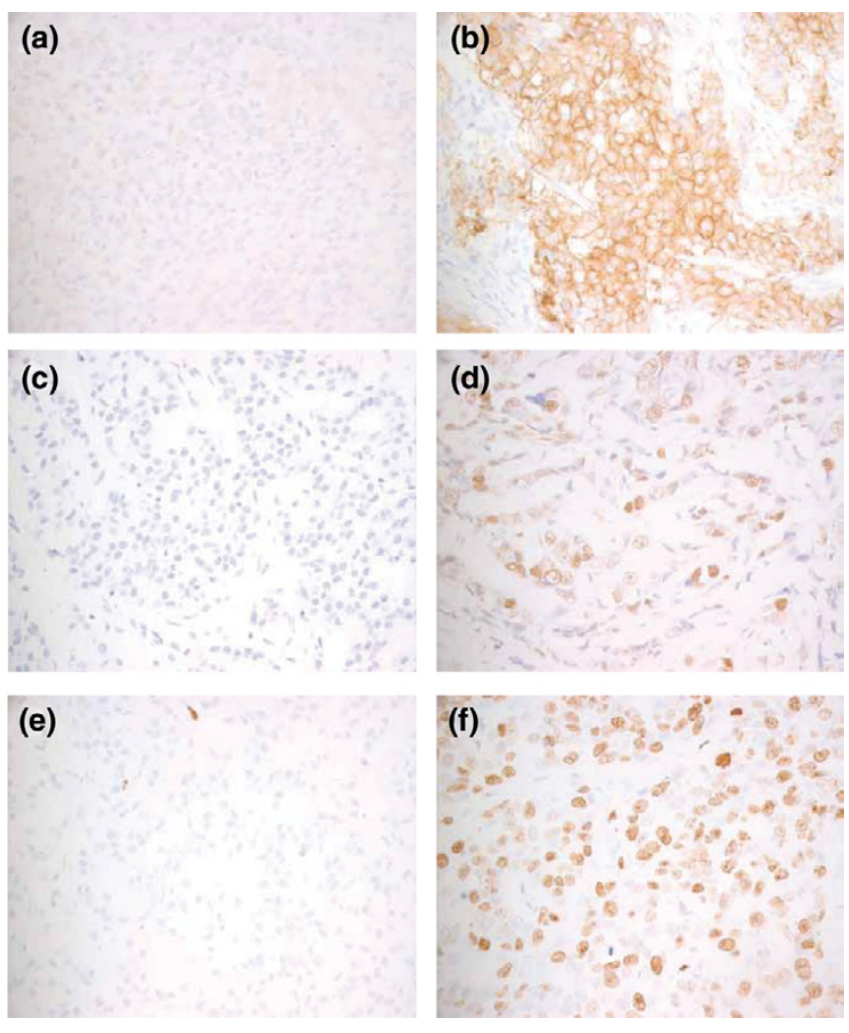

Representative immunohistochemical staining of HER2, p53, and Ki67 in invasive ductal carcinoma. (a) Negative staining of HER2. (b) Positive staining of HER2. (c) Negative staining of p53. (d) Positive staining of p53. (e) Negative staining of Ki67. (f) Positive staining of Ki67.

human PgR antibody (636; Dako Denmark A/S) at 1:100 dilution for PR, rabbit anti-human c-erbB-2 oncoprotein antibody (Dako Denmark A/S) at 1:200 dilution for HER2, monoclonal mouse anti-human p53 protein antibody (PAb1801; Novocastra, Newcastle, UK) at 1:50 dilution for p53, and monoclonal mouse anti-human Ki67 antibody (MIB-1; Dako Denmark A/S) at 1:100 dilution for Ki67. The Dako Denmark A/S EnVision system (Dako Denmark A/S EnVision labeled polymer, peroxidase) was used as the detection system for ER- $\alpha, P R, H E R 2$, and Ki67. The streptavidin-biotin system (SAB-PO kit; Nichirei Co., Inc., Tokyo, Japan) was used for detection of the bound antibody

of

p53.

\section{Immunohistochemical scoring}

Immunostained slides were scored after the entire slide was evaluated by light microscopy. The expression of ER- $\alpha$ and PR was scored by assigning proportion and intensity scores, in accordance with the procedure of Allred and colleagues [29]. Any brown nuclear staining in invasive breast epithelium was counted toward the proportion score. Tumours with a score of 3 or greater were considered to be positive for ER- $\alpha$ and PR expression. HER2 immunostaining was evaluated by the same method as the HercepTest (Dako Denmark A/S). To determine the score of HER2 expression, the membrane staining pattern
Figure 2

(a)

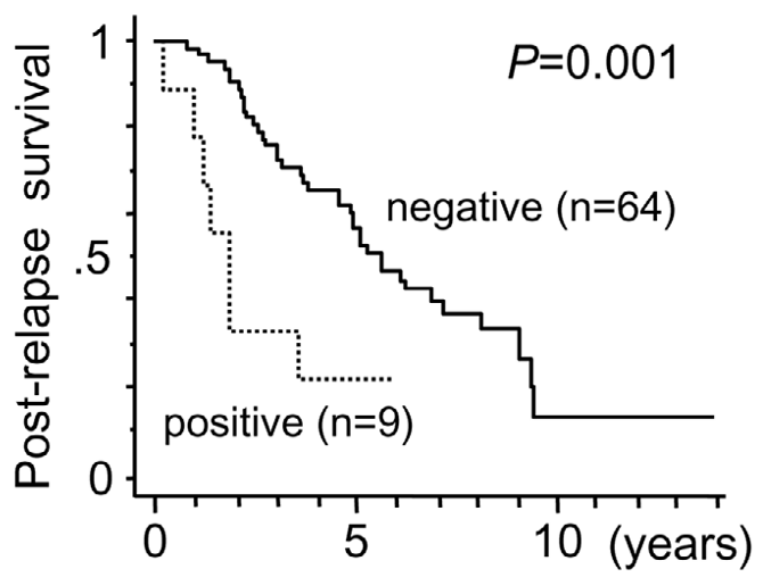

(b)

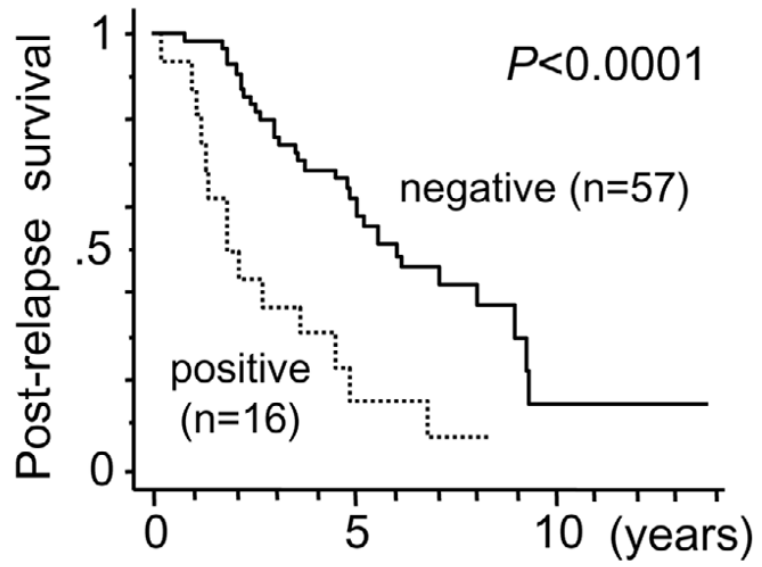

(c)

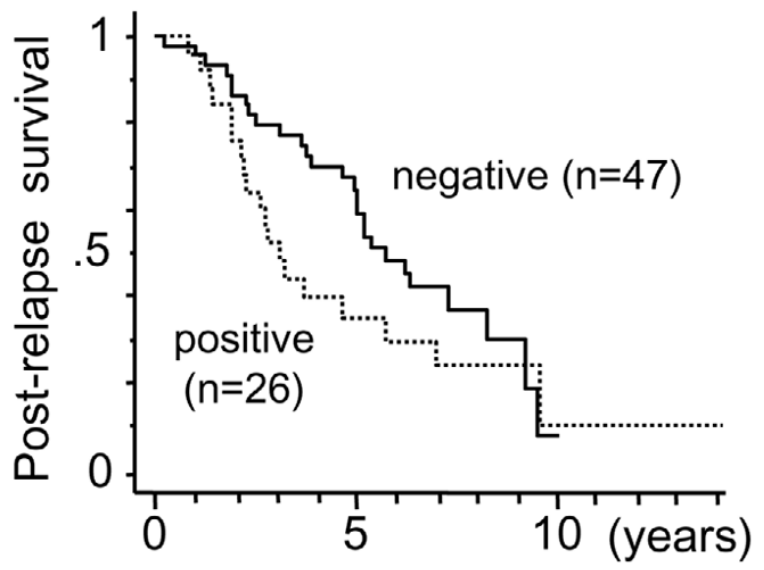

Post-relapse survival according to HER2 overexpression, p53 protein accumulation, and Ki67 expression. (a) Post-relapse survival according to HER2 overexpression. (b) Post-relapse survival according to p53 protein accumulation. (c) Post-relapse survival according to Ki67. HER2 overexpression and p53 protein accumulation significantly reduced post-relapse survival. 
was estimated and scored on a scale of 0 to 3 . Tumours with a score of 3 were considered to be positive for HER2 overexpression. The expression status of p53 and Ki67 was assessed according to the estimated proportion of nuclear staining of tumour cells that were positively stained as described previously [11]. Scoring criteria were as follows: for p53, score of $0=$ none; score of $1,<1 / 10$; score of $2,1 / 10$ to $1 / 2$; and score of $3,>1 / 2$; for Ki67, score of $0=$ none; score of $1,<1 / 100$; score of $2,1 / 100$ to $1 / 10$; score of $3,1 / 10$ to $1 / 2$; and score of $4,>1 / 2$. Tumours with a score of 2 or greater for $\mathrm{p} 53$ were considered to be positive for p53 protein accumulation, and tumours with a score of 3 or greater for Ki67 were considered to be positive for Ki67 expression.

\section{Statistical analysis}

The $\chi^{2}$ test was used to compare the immunohistochemical results of molecular markers with clinicopathological characteristics and response to endocrine therapy. Estimation of post-relapse survival was performed using the Kaplan-Meier method, and differences between survival curves were assessed with the log-rank test. Cox's proportional hazards model was used for univariate and multivariate analyses of prognostic values.

\section{Results \\ Correlation between HER2, p53, and Ki67 expression and clinicopathological factors}

We examined expression of HER2, p53, and Ki67 in primary invasive breast carcinomas by IHC from 73 patients with metastatic breast cancer who received endocrine therapy as firstline treatment on relapse (Figure 1). The immunohistochemical status for HER2, p53, and Ki67 was compared among patient subgroups according to clinicopathological factors. Of the 73 invasive ductal carcinomas, $12.3 \%, 21.9 \%$, and $35.6 \%$ were positive for HER2 overexpression, p53 protein accumulation, and Ki67 expression, respectively (Table 2). No association was found between HER2 overexpression, p53 protein accumulation, or Ki67 expression and clinicopathological factors. p53 protein accumulation and Ki67 expression in primary breast tumours are predictive of endocrine therapy resistance in metastatic breast cancer

At relapse, all patients received endocrine therapy as first-line treatment for metastatic breast cancer; 34 patients $(46.6 \%)$ responded. We analysed whether the expression status of HER2, p53, and Ki67 in the primary breast tumours affected the response to endocrine therapy in this setting (Table 3 ). Patients with primary breast tumours that had p53 protein accumulation and Ki67 expression were significantly more likely to exhibit resistance to endocrine therapy $(P=0.0049$ and $P=0.024$, respectively). Patients with HER2 overexpression also showed a tendency for greater resistance to endocrine therapy $(P=0.054)$, but the trend did not reach statistical significance.

\section{Patients with HER2 overexpression and p53 protein accumulation in primary breast tumours had a significantly shorter survival after relapse}

We analysed whether expression status of HER2, p53, and Ki67 in the primary breast tumours affected survival after relapse. The median follow-up period was 77 months (range, 4 to 234 months). HER2 overexpression significantly reduced post-relapse survival $(P=0.001)$ (Figure 2a) by log-rank test. Moreover, patients with p53 protein accumulation had a significantly shorter post-relapse survival $(P<0.0001)$ (Figure $2 b)$. Univariate analysis (Table 4 ) demonstrated significant associations between post-relapse survival and HER2 overexpression $(P=0.0024)$ and p53 protein accumulation $(P=0.0002)$ as well as expression ER- $\alpha(P=0.0009)$ and PR $(P=0.0012)$ expression. On the other hand, Ki67 expression did not affect post-relapse survival. The status of expressions of ER- $\alpha$, PR, HER2, and p53 were selected for the multivariate analysis. Patients with primary tumours with HER2 overexpression $(P=$ $0.0046)$ and $p 53$ protein accumulation $(P=0.013)$ had significantly reduced post-relapse survival, whereas those with positive expression of PR had significantly increased post-relapse survival $(P=0.045)$ (Table 4$)$. We conclude that HER2 overexpression and p53 protein accumulation are independent prognostic factors of post-relapse survival in patients with met-

Table 3

Correlation between immunohistochemical status of HER2, p53, and Ki67 and response to endocrine therapy

\begin{tabular}{|c|c|c|c|c|c|c|}
\hline & \multicolumn{2}{|c|}{ HER2 } & \multicolumn{2}{|c|}{ P53 } & \multicolumn{2}{|c|}{ Ki67 } \\
\hline & $\begin{array}{l}\text { Positive/total } \\
\text { (percentage) }\end{array}$ & $P$ & $\begin{array}{l}\text { Positive/total } \\
\text { (percentage) }\end{array}$ & $P$ & $\begin{array}{l}\text { Positive/total } \\
\text { (percentage) }\end{array}$ & $P$ \\
\hline \multicolumn{7}{|c|}{ Response to endocrine therapy $(n=73)$} \\
\hline Total & $9 / 73(12.3)$ & & $16 / 73(21.9)$ & & 26/73 (35.6) & \\
\hline Responders & $1 / 34(2.9)$ & 0.054 & $2 / 34(5.9)$ & $0.0049^{a}$ & $7 / 34(20.6)$ & $0.024^{a}$ \\
\hline Non-responders & $8 / 39$ (20.5) & & 14/39 (35.9) & & 19/39 (48.7) & \\
\hline
\end{tabular}

a $P<0.05$ is considered significant. 
astatic breast cancer who received first-line treatment with endocrine therapy on relapse.

\section{Discussion}

The present study indicates that p53 protein accumulation predicts resistance to endocrine therapy and decreased postrelapse survival in patients with metastatic breast cancer who received first-line treatment with endocrine therapy on relapse.

Experimental data suggest a complex cross-talk between HER2 and ER, and it has been hypothesised that HER2-positive tumours may be less responsive to certain endocrine treatments. However, it has yet to be established whether HER2 overexpression is predictive of resistance to endocrine therapy, whether used as an adjuvant therapy after excision of localised breast cancer or as treatment for metastatic disease. In the metastatic setting, several groups have identified a correlation between HER2 overexpression and a lower response rate to endocrine therapy, whereas others have not. De Laurentiis and colleagues recently conducted a meta-analysis of the published studies to obtain an overall pooled estimate of the association between HER2 overexpression and treatment failure rate [6]. They found that HER2-positive metastatic breast cancer was less responsive to any type of endocrine therapy. Our data failed to show an association between HER2 overexpression and resistance to endocrine therapy, possibly due to the small number of patients in our study. Nevertheless, HER2 overexpression significantly reduced postrelapse survival.

It has been reported from three groups of clinical trials that p53 status by IHC does not predict response to tamoxifen [23-25]. Elledge et al. found that p53 expression as measured by $\mathrm{IHC}$ was not associated with response to tamoxifen in 205 patients with metastatic breast cancer, although patients with higher p53 had a worse survival [25]. It has also been reported not to predict tamoxifen resistance in ER-positive, node-positive breast cancer [24] or in high-risk postmenopausal breast cancer [23] in adjuvant studies. In contrast, Berns et al. found that in 401 patients with metastatic breast cancer, p53 expression as measured by enzyme immunoassay of cytoplasmic extracts from primary tumours was a predictor of tamoxifen resistance [27]. Our results indicate that $\mathrm{p} 53$ protein accumulation by IHC was predictive of endocrine therapy resistance and decreased post-relapse survival in metastatic breast cancer. The antibody for p53 that Elledge et al. [25] used was also used in our study. Their results may have differed from ours because not only tamoxifen, but also aromatase inhibitors and/ or LHRH (luteinising hormone-releasing hormone) agonists, were used as endocrine therapy in our study. Further studies to analyse the correlation between response to each endocrine therapy agent and p53 status are necessary to understand the role of $\mathrm{p} 53$ in endocrine therapy resistance. Moreover, the conflicting results may be caused by the different evaluation methods of p53 status. Geisler et al. demonstrated that nearly $30 \%$ of all mutations in primary breast cancer, in particular those of the nonsense type, are not detected by $\mathrm{IHC}$ and that most studies evaluating p53 status by $\mathrm{IHC}$ have failed to show a predictive value of p53 for chemotherapy, whereas studies evaluating p53 status by DNA sequencing have reported mutations that predict resistance to chemotherapy [15]. Therefore, mutational analysis of p53 might be helpful in evaluating the association between p53 status and endocrine therapy resistance.

\section{Conclusion}

The present study indicates that p53 protein accumulation predicts resistance to endocrine therapy and decreased postrelapse survival in patients with metastatic breast cancer who received first-line treatment with endocrine therapy on relapse.

Table 4

Prognostic factors in $\mathbf{7 3}$ invasive ductal carcinomas compared with post-relapse survival

\begin{tabular}{|c|c|c|c|c|c|c|}
\hline & \multicolumn{3}{|c|}{ Univariate } & \multicolumn{3}{|c|}{ Multivariate } \\
\hline & $P$ & $\mathrm{RR}$ & $95 \% \mathrm{Cl}$ & $P$ & RR & $95 \% \mathrm{Cl}$ \\
\hline Age & 0.67 & 0.882 & $0.494-1.576$ & & & \\
\hline Tumour size & 0.21 & 1.483 & $0.797-2.759$ & & & \\
\hline $\begin{array}{l}\text { Lymph node } \\
\text { status }\end{array}$ & 0.40 & 0.746 & $0.376-1.479$ & & & \\
\hline Histological grade & 0.15 & 0.500 & $0.197-1.271$ & & & \\
\hline ER- $\alpha$ & $0.0009^{a}$ & 0.342 & $0.181-0.645$ & 0.79 & 1.174 & $0.354-3.886$ \\
\hline PR & $0.0012^{a}$ & 0.358 & $0.192-0.668$ & $0.045^{a}$ & 0.291 & $0.087-0.972$ \\
\hline HER2 & $0.0024^{a}$ & 3.637 & $1.582-8.362$ & $0.0046^{a}$ & 3.710 & $1.498-9.191$ \\
\hline p53 & $0.0002^{a}$ & 3.371 & $1.765-6.440$ & $0.013^{a}$ & 2.364 & $1.198-4.665$ \\
\hline Ki67 & 0.16 & 1.539 & $0.849-2.790$ & & & \\
\hline
\end{tabular}

a $P<0.05$ is considered significant. $\mathrm{Cl}$, confidence interval; ER, estrogen receptor; PR, progesterone receptor; RR, relative risk. 
Our data suggest that p53 protein accumulation is helpful in selecting patients who may benefit from endocrine therapy and is a prognostic marker in metastatic breast cancer.

\section{Competing interests}

The authors declare that they have no competing interests.

\section{Authors' contributions}

HY conceived of the study and participated in its design, coordination, and manuscript writing. MN carried out immunostaining experiments. SK, YF, and $\mathrm{HI}$ participated in its design and coordination and helped to draft the manuscript. TT, YA, and $\mathrm{MH}$ provided tissue samples. $\mathrm{HY}$ and $\mathrm{ZZ}$ assessed the immunostaining. All authors read and approved the final manuscript.

\section{Acknowledgements}

This work was supported by Grants-in Aid for Scientific Research from the Ministry of Education, Science, Sports and Culture in Japan 16591267.

\section{References}

1. Johnston SR, Head J, Pancholi S, Detre S, Martin LA, Smith IE, Dowsett M: Integration of signal transduction inhibitors with endocrine therapy: an approach to overcoming hormone resistance in breast cancer. Clin Cancer Res 2003, 9:524S-532S.

2. Schiff R, Massarweh S, Shou J, Osborne CK: Breast cancer endocrine resistance: how growth factor signaling and estrogen receptor coregulators modulate response. Clin Cancer Res 2003, 9:447S-454S.

3. Elledge RM, Green S, Ciocca D, Pugh R, Allred DC, Clark GM, Hill J, Ravdin P, O'Sullivan J, Martino S, et al.: HER-2 expression and response to tamoxifen in estrogen receptor-positive breast cancer: a Southwest Oncology Group Study. Clin Cancer Res 1998, 4:7-12.

4. Yamauchi $\mathrm{H}$, Stearns $\mathrm{V}$, Hayes DF: When is a tumor marker ready for prime time? A case study of c-erbB-2 as a predictive factor in breast cancer. J Clin Oncol 2001, 19:2334-2356.

5. Stal O, Borg A, Ferno M, Kallstrom AC, Malmstrom P, Nordenskjold B: ErbB2 status and the benefit from two or five years of adjuvant tamoxifen in postmenopausal early stage breast cancer. Ann Oncol 2000, 11:1545-1550.

6. De Laurentiis M, Arpino G, Massarelli E, Ruggiero A, Carlomagno C, Ciardiello F, Tortora G, D'Agostino D, Caputo F, Cancello G, et al:: A meta-analysis on the interaction between HER-2 expression and response to endocrine treatment in advanced breast cancer. Clin Cancer Res 2005, 11:4741-4748.

7. Fitzgibbons PL, Page DL, Weaver D, Thor AD, Allred DC, Clark GM, Ruby SG, O'Malley F, Simpson JF, Connolly JL, et al.: Prognostic factors in breast cancer. College of American Pathologists Consensus Statement 1999. Arch Pathol Lab Med 2000, 124:966-978.

8. Hurlimann J, Chaubert P, Benhattar J: p53 Gene alterations and p53 protein accumulation in infiltrating ductal breast carcinomas: correlation between immunohistochemical and molecular biology techniques. Mod Pathol 1994, 7:423-428.

9. Kerns BJ, Jordan PA, Moore MB, Humphrey PA, Berchuck A, Kohler MF, Bast RC Jr, Iglehart JD, Marks JR: p53 overexpression in formalin-fixed, paraffin-embedded tissue detected by immunohistochemistry. J Histochem Cytochem 1992, 40:1047-1051.

10. Elledge RM, Allred DC: The p53 tumor suppressor gene in breast cancer. Breast Cancer Res Treat 1994, 32:39-47.

11. Yamashita $H$, Nishio M, Toyama $T$, Sugiura $H$, Zhang $Z$, Kobayashi $\mathrm{S}$, Iwase $\mathrm{H}$ : Coexistence of HER2 over-expression and p53 protein accumulation is a strong prognostic molecular marker in breast cancer. Breast Cancer Res 2004, 6:R24-30.
12. Lowe SW, Bodis S, McClatchey A, Remington L, Ruley HE, Fisher DE, Housman DE, Jacks T: p53 status and the efficacy of cancer therapy in vivo. Science 1994, 266:807-810.

13. Kandioler-Eckersberger D, Ludwig $C$, Rudas $M$, Kappel $S$, Janschek E, Wenzel C, Schlagbauer-Wadl H, Mittlbock M, Gnant M, Steger $\mathrm{G}$, et al.: TP53 mutation and p53 overexpression for prediction of response to neoadjuvant treatment in breast cancer patients. Clin Cancer Res 2000, 6:50-56.

14. Thor AD, Berry DA, Budman DR, Muss HB, Kute T, Henderson IC, Barcos M, Cirrincione C, Edgerton S, Allred C, et al.: erbB-2, p53, and efficacy of adjuvant therapy in lymph node-positive breast cancer. J Natl Cancer Inst 1998, 90:1346-1360.

15. Geisler S, Lonning PE, Aas T, Johnsen H, Fluge O, Haugen DF, Lillehaug JR, Akslen LA, Borresen-Dale AL: Influence of TP53 gene alterations and c-erbB-2 expression on the response to treatment with doxorubicin in locally advanced breast cancer. Cancer Res 2001, 61:2505-2512.

16. Aas T, Borresen AL, Geisler S, Smith-Sorensen B, Johnsen H, Varhaug JE, Akslen LA, Lonning PE: Specific P53 mutations are associated with de novo resistance to doxorubicin in breast cancer patients. Nat Med 1996, 2:811-814.

17. Rahko E, Blanco G, Soini Y, Bloigu R, Jukkola A: A mutant TP53 gene status is associated with a poor prognosis and anthracycline-resistance in breast cancer patients. Eur J Cancer 2003 39:447-453.

18. Clahsen PC, van de Velde CJ, Duval C, Pallud C, Mandard AM, Delobelle-Deroide A, van den Broek L, Sahmoud TM, van de Vijver $\mathrm{MJ}$ : p53 protein accumulation and response to adjuvant chemotherapy in premenopausal women with node-negative early breast cancer. J Clin Oncol 1998, 16:470-479.

19. Bertheau $P$, Plassa $F$, Espie $M$, Turpin E, de Roquancourt $A$, Marty $M$, Lerebours F, Beuzard $Y$, Janin A, de The H: Effect of mutated TP53 on response of advanced breast cancers to high-dose chemotherapy. Lancet 2002, 360:852-854.

20. Askmalm MS, Carstensen J, Nordenskjold B, Olsson B, Rutqvist LE, Skoog L, Stal O: Mutation and accumulation of p53 related to results of adjuvant therapy of postmenopausal breast cancer patients. Acta Oncol 2004, 43:235-244.

21. Andersson J, Larsson $L$, Klaar S, Holmberg L, Nilsson J, Inganas $M$, Carlsson G, Ohd J, Rudenstam CM, Gustavsson B, et al:: Worse survival for TP53 (p53)-mutated breast cancer patients receiving adjuvant CMF. Ann Oncol 2005, 16:743-748.

22. Geisler $\mathrm{S}$, Borresen-Dale AL, Johnsen $H$, Aas T, Geisler J, Akslen LA, Anker G, Lonning PE: TP53 gene mutations predict the response to neoadjuvant treatment with 5 -fluorouracil and mitomycin in locally advanced breast cancer. Clin Cancer Res 2003, 9:5582-5588.

23. Knoop AS, Bentzen SM, Nielsen MM, Rasmussen BB, Rose C: Value of epidermal growth factor receptor, HER2, p53, and steroid receptors in predicting the efficacy of tamoxifen in high-risk postmenopausal breast cancer patients. J Clin Oncol 2001, 19:3376-3384.

24. Berry DA, Muss HB, Thor AD, Dressler L, Liu ET, Broadwater G, Budman DR, Henderson IC, Barcos M, Hayes D, et al:: HER-2/ neu and p53 expression versus tamoxifen resistance in estrogen receptor-positive, node-positive breast cancer. J Clin Oncol 2000, 18:3471-3479.

25. Elledge RM, Green S, Howes L, Clark GM, Berardo M, Allred DC, Pugh R, Ciocca D, Ravdin P, O'Sullivan J, et al:: bcl-2, p53, and response to tamoxifen in estrogen receptor-positive metastatic breast cancer: a Southwest Oncology Group study. J Clin Oncol 1997, 15:1916-1922.

26. Archer SG, Eliopoulos A, Spandidos D, Barnes D, Ellis IO, Blamey RW, Nicholson RI, Robertson JF: Expression of ras p21, p53 and c-erbB-2 in advanced breast cancer and response to first line hormonal therapy. Br J Cancer 1995, 72:1259-1266.

27. Berns EM, Klijn JG, van Putten WL, de Witte HH, Look MP, Meijervan Gelder ME, Willman K, Portengen H, Benraad TJ, Foekens JA: p53 protein accumulation predicts poor response to tamoxifen therapy of patients with recurrent breast cancer. $J$ Clin Oncol 1998, 16:121-127.

28. Yamashita H, Nishio M, Kobayashi S, Ando $Y$, Sugiura $H$, Zhang Z, Hamaguchi M, Mita K, Fujii Y, Iwase H: Phosphorylation of estrogen receptor alpha serine 167 is predictive of response to endocrine therapy and increases postrelapse survival in metastatic breast cancer. Breast Cancer Res 2005, 7:R753-764. 
Breast Cancer Research Vol 8 No 4 Yamashita et al.

29. Allred DC, Harvey JM, Berardo M, Clark GM: Prognostic and predictive factors in breast cancer by immunohistochemical analysis. Mod Pathol 1998, 11:155-168. 